\title{
In for a Penny, or: If You Disapprove of Investment Migration, Why Do You Approve of High-Skilled Migration?
}

\author{
Lior Erez, Hebrew University of Jerusalem \\ Forthcoming in Moral Philosophy E Politics
}

\begin{abstract}
While many argue investment-based criteria for immigration are wrong or at least problematic, skill-based criteria remain relatively uncontroversial. This is normatively inconsistent. This article assesses three prominent normative objections to investment-based selection criteria for immigrants: (i) that they wrongfully discriminate between prospective immigrants (ii) that they are unfair, and (iii) that they undermine political equality among citizens. It argues that either skill-based criteria are equally susceptible to these objections, or that investment-based criteria are equally shielded from them. Indeed, in some ways investment-based criteria are less normatively problematic than skill-based criteria. Given this analysis, the resistance to investment-based migration criteria, but not to skill-based criteria, is inconsistent.
\end{abstract}

Keywords: Discrimination; Ethics of Immigration; Equality of Opportunity; Investment Migration; Political Equality

\section{Introduction}

Much of the existing normative literature on migration has revolved around the question of exclusion and the rights of the excluded: the desirability and feasibility of open borders, the rights of refugees and other vulnerable groups to enter, and the different justifications for states to limit immigration (cf. Fine and Ypi 2016; Ferracioli 2017). Yet two emerging patterns in global migration - skill-based and investmentbased migration - highlight strikingly different questions. In contrast with the image of states struggling to restrict immigration, skill- and investment-based immigrants are welcomed, actively recruited, and indeed fought over by states.

Skill-based migration is the more visible trend, as more and more states are engaging in the intense global competition to attract internationally mobile human capital. Czaika and Parsons estimate that 'two-thirds of OECD nations having implemented, or [are] in the process of implementing, policies specifically aiming to attract high- 
skilled migrants' (2017, p. 604). Less visible is the growing number of states offering 'golden visas', permanent residence, and sometimes even full citizenship status, in exchange for investment (in real-estate, sovereign development funds, or local business). In the European Union, about half of member states now have dedicated investor migration routes, with Malta and Cyprus offering (controversial) citizenshipby-investment. Similar programs exist, or are under development, in other parts of the world as well.

Scholars have rightly pointed out that these two trends are related through a changing attitude of states to migration, the influence of globalization, and the rise of a mobile transnational elite (Van Fossen 2007; Shachar and Hirschl 2014; Abrahamian 2015; Parker 2017; Džankić 2019). Both are instances of discretionary migration policies: unlike refugees and asylum seekers, or particular cases of family reunification, these are cases where states are assumed to hold the right to select prospective immigrants. Yet, interestingly, while skill-based migration is generally seen, both in the public discourse and in most of the academic scholarship, as desired and uncontroversial with skill-based criteria (hereafter SBC) sometimes as the only legitimate criteria for selection (Joppke 2005) - investment-based criteria (hereafter: IBC) have been met with an overwhelming resistance. While defences of the practice do exist (Borna and Stearns 2002; Becker and Lazear 2013; Hidalgo 2016), the general consensus is that selecting immigrants by their ability to pay is problematic, or at least more problematic than selecting immigrants by skill (Johnston 2013; Shachar and Hirschl 2014; Shachar 2017; Shachar 2018; Tanasoca 2018). As even those who are sceptical about the merits of skill-based migration write, 'The emphasis on skills and talent is certainly preferable to using the size of applicants' wallets to determine who to bring in and who to keep out' (Shachar and Hirschl 2014, p. 253).

In this paper, I argue that this common view is unfounded and inconsistent. By examining three prominent normative objections to IBC, I show that (i) these objections apply to SBC equally, or even to a greater degree, and (ii) insofar as defenders of SBC are able to accommodate these objections, these accommodations apply equally (and sometimes more so) to IBC. This is not intended as a condemnation of SBC nor as approbation of IBC; I merely argue that endorsing the former should lead one, on pain of inconsistency, to endorse the latter (and vice versa). The position I am arguing against is the one that finds SBC acceptable and IBC unacceptable.

I will first provide the preliminary background assumptions for the comparison. In the following sections, I will explore three possible dimensions in which selective criteria for discretionary immigration are criticised: whether they wrongfully discriminate, or are unfair to, prospective unselected immigrants; or whether they wrong existing citizens in immigration-receiving states by violating political equality. 
In each of these categories, I will argue that IBC does not fare worse, and in some cases fares better, than SBC.

The list of objections I consider below is not exhaustive, and there are two significant omissions I wish to explicitly point out. One important objection not directly addressed in this analysis appeals to the ethical limits of commodification, arguing that political membership is intrinsically 'not for sale' (e.g. Shachar 2017, pp.806f). While I am sceptical about such intrinsic arguments (cf. Brennan and Jaworski 2015), defending this scepticism is beyond the scope of my argument. I do, however, address the non-intrinsic case against selling citizenship when discussing arguments appealing to Walzerian complex equality (in 4.2.), and expressive harm (in 5.2.).

I will also, for limits of scope, focus only on arguments relating to the prospective immigrants and the citizens of the receiving state, and not discuss the important question of the potential externalities of these policies on migration-sending states and their non-migrant population. This omission is warranted, I hope, given the fact that such externalities of SBC - e.g., the human capital flight implications of skill-based emigration (the 'brain drain' question) - are already well discussed and visible in the literature (Brock and Blake 2014). An analogous argument could be made with regards to IBC as a method of tax evasion by the wealthy. My aim in this article, however, is to demonstrate how objections to IBC can be applied to SBC, and not the other way around.

\section{Preliminary Assumptions}

Before turning to the comparative evaluation of SBC and IBC, it will be helpful to explicitly state the background assumptions I will be employing in this analysis. ${ }^{1}$ Throughout, I will assume that (1) states have the presumptive right to limit immigration, and while (2) this power to exclude prospective immigrants is constrained by considerations of human rights and legitimacy (for example, vis-à-vis refugees), (3) both skill-based migration and investment-based migration are open to the discretion of states, under weaker constraints of justification. In order to assess whether these selection criteria meet the burden of justification, we have to (4) assume all other features of these policies being equal.

The rationale for endorsing these assumptions is both tactical and methodological. First, the first three assumptions conform to what I take to be the mainstream position in the ethics of migration policy, encompassing a wide spectrum of the theoretical

\footnotetext{
1 These assumptions are not self-evident; for prominent methodological critiques of their implicit acceptance in most of the ethical literature on migration, see (Cole 2014; Sager 2016). My aim in this article is not to defend these assumptions.
} 
positions in the literature (though not all - as I explain below, I do not address the open borders position, for example). By working from widely accepted assumptions, I hope to make my conclusion more compelling. Second, working from these four background assumptions allows me to make the case that objections to IBC apply equally to SBC, without arriving at this conclusion by fiat. Let us now turn to explain each of the four assumption in more detail.

(1) First, my analysis assumes that states have a presumptive right to impose at least some limits on immigration. This assumption could be interpreted more or less broadly, of course, but it is meant to exclude the 'open border' position: that freedom of movement across borders ought to be free, or that there is a general human right to immigrate.

As I mentioned above, one motivation for this assumption is ecumenical, as the open border argument is a contested position within immigration ethics. However, my exclusion of the open borders assumption is methodological, not substantive. Accepting that there is a strong right to global freedom of movement would obviate the comparison between SBC and IBC, or indeed between any discretionary selection criteria whatsoever; they would all be prohibited. In other words, the argument I wish to defend - that the different evaluation of SBC and IBC is inconsistent - will be confirmed by definition.

(2) Second, the presumptive right to impose limits on immigration is not absolute and is not entirely open to the unilateral discretion of states. Considerations of human rights, with regards to general claims of refugees and asylum seekers, and particular claims of family reunification, are seen grounding strong rights to migrate, and constrain the state's right to exclude.

It is important to note that unlike the argument for open borders, which is endorsed by at least some normative theorists, the absolute control argument is not supported by any normative theorist of which I am aware. Furthermore, this assumption is methodologically justified for the same reason as the previous one: if states have absolute authority to decide on the limits of immigration, then all selection criteria would be equally permitted.

(3) I will moreover assume that claims of migrants considered under skill-based and investment-based migration policy do not pose strong constraints on the state's right to exclude them, but that this right to exclude is still subject to demands of justification. This assumption could be stated as such: while it is within the state's right to exclude some or all potential immigrants who fall under this category, it is obliged to provide a justification in case it chooses to employ any selection criteria between prospective 
immigrants. Assessing and comparing SBC and IBC, in other words, would involve considering whether the specific criteria are justifiable.

But justifiable to whom? This is a complex question which can have more or less controversial answers. Least controversially, I will assume that immigration policy as all public policy, at least in democracies - has to be justifiable to the state's citizenry (Blake 2002, 2008). In some cases, I will also assume that selection criteria should be justifiable to prospective migrants that will be excluded. This requirement of justification may arise from different foundations, for example, a weak cosmopolitan principle of equal respect to all (Miller 2016), an application of the all-affected principle in democratic theory (Goodin 2007), or from seeing immigration controls as a form of coercion, which has to be legitimated by justification (Abizadeh 2008). Each of these foundations will suggest a different threshold of sufficient justification, and it is well beyond the scope of this paper to adjudicate between them (cf. Yong 2017). For my purposes, I will apply the same level of required justification when considering objections to IBC and SBC. So, for example, if an objection to IBC supposes that it is unjustifiable to prospective immigrants because it does not meet justificatory threshold X, I will ask whether SBC meet this threshold. ${ }^{2}$

(4) Fourth, and finally, in order to appropriately evaluate and compare the strength of justifications for SBC and IBC, we have to be able to compare like-for-like, and consider these selection criteria on equal basis. I highlight this necessity because of the unfortunate tendency of some writers to support their case against IBC by compounding the supposed wrongs of the practice, while at the same time evaluating SBC according to its best interpretation. A fair assessment of these policies should not take into account, for example, accusations of democratic illegitimacy of investorbased migration, as was made by the Maltese opposition in 2014; if true, that would certainly constitute a wrong, but not one necessarily due to the selection criterion itself. One must also avoid turning to slippery slope argument, conflating discretionary selection of immigrants according to the ability to pay ('golden visas'), the exchange of citizenship for investment without any residency requirements, and the outright commodification of citizenship in an open market. Given that for each of these variations there is an equivalent policy based on selection by skill (for example, the quick naturalisation of Olympic athletes), comparing uncontroversial admissions of high-skilled workers to the radical and hypothetical barter of citizenship dreamt up by some economists would only serve to make comparison less clear.

With these preliminary assumptions stated, I turn now to investigate potential burdens of justifications for selection criteria in migration.

\footnotetext{
${ }^{2}$ I am thankful to an anonymous referee for pressing me to clarify this point.
} 


\section{The Wrongful Discrimination Objection}

In its motion on the question of citizenship for sale, the European Parliament stated that 'concerns exist as regards possible discrimination because these practices by Member States only allow the richest third-country nationals to obtain EU citizenship, without any other criteria being considered' (European Parliament 2014). Clearly, IBC discriminate between prospective migrants: it discriminates between those able to pay and those who are not able.

Interpreted this broadly, the claim is both trivial and too general: all selection criteria would be discriminating in this sense, including SBC (they would discriminate between the skilled and the unskilled). This is not sufficient for demonstrating that investment-based criteria are wrongfully discriminating. As Javier Hidalgo writes,

When people sell luxury cars, mansions, or expensive antique furniture, they discriminate against poor people. These people in effect treat poor people worse than rich people by selling products that only rich people can afford. Nonetheless, it appears permissible to sell luxury goods to rich people (2016, p. 236).

We of course do consider certain selection criteria for immigrants to be wrongfully discriminatory. Article 26 of The International Covenant on Civil and Political Rights prohibits discrimination on grounds such as 'race, color, sex, language, religion, political or other opinion, national or social origin, property, birth or other status'. Most theorists who justify the state's right to exclude also accept that the state is not permitted to exclude prospective immigrants based on their ethnicity, gender, or religion - while admittedly the question of language and place of birth is murkier. ${ }^{3}$ But on what grounds are these criteria wrongfully discriminatory, and can skill- and investment-based criteria be analogously held to be wrongful?

In order to answer this question, I turn to the philosophical literature on the concept of wrongful discrimination, and the proposed accounts of the wrongfulness of discrimination: following Kasper Lippert-Rasmussen's typology (2014), I will consider three prominent accounts: the Mental State based account, the Objective Meaning account, and the Harm based account. It is beyond the scope of this paper to defend any of these accounts as the primary ground for the wrongness of discrimination, either with regards to particular wrongness of race-based criteria for

\footnotetext{
${ }^{3}$ See works by David Miller (2016), Christopher Wellman (2011), Ryan Pevnick (2011), Michael Blake (2002), with Michael Walzer (1983) as the most prominent counterexample. Wellman believes that these criteria are wrong, but interestingly writes that 'I must confess, however, that I find it surprisingly difficult to provide an entirely satisfying argument for this conclusion' (2011, p. 144).
} 
selecting immigrants or the broader concept. Suffice to show that whatever account one finds most convincing, it applies equally to SBC and IBC.

\subsection{Mental State}

Mental State Based accounts of discrimination, such as that defended in an influential article by Larry Alexander, maintain that what makes discrimination wrong is the wrongful mental state (e.g. one's attitude, motive, or intention) of the discriminator: the thought that the one discriminated against was of inferior moral worth (Alexander 1992). ${ }^{4}$ Since all people are of equal moral worth, this expresses the wrong view, and is disrespectful. So for race-based selection criteria, one may argue that they are wrong since they are motivated by the false belief that, in the example of the American Chinese Exclusion Act, Chinese prospective immigrants are morally inferior to whites. ${ }^{5}$ A related thought is expressed by David Miller, who writes that to be told that they are the wrong race, or sex (or have the wrong hair color) is insulting [to prospective immigrants], given that these features do not connect to anything of real significance to the society they want to join'. ${ }^{6}$

But this account does not easily apply to the selection criteria I am considering here. The paradigmatic example in this account is an employer hiring a lesser skilled candidate because of a false belief about moral superiority based on race. ${ }^{7}$ But for both SBC and IBC, the analogy does not hold. While it is true that states have, in the past, designed immigration policies with the expressed intent of excluding some groups perceived as morally inferior, it is less clear that the state must hold any view on the moral worth of prospective immigrants by using economic criteria: instead, it only needs to take into account the economic benefit they would bring its society. If we analogise selecting between prospective immigrants to selecting job candidates, then these criteria are permissible in the same way that hiring someone who would bring more useful skills to the company (the equivalent of SBC) or someone who would be less costly (the equivalent of IBC) are permissible. Douglas MacKay argues that, since '[e]conomic success is a legitimate aim of government because it can be reasonably expected to facilitate the realization of states' legitimate purposes in securing and

\footnotetext{
${ }^{4}$ Note however, that in more recent writing Alexander explicitly rejects this account (and indeed, all philosophical accounts) of the wrongness of discrimination (Alexander 2016).

5 'The popular and intellectual debates regarding migration and naturalization were framed in racial terms. For instance, Chinese laborers were maligned as "docile", "servile", and "unfit" for selfgovernment.' (Fine 2016)

${ }^{6}$ Strictly speaking, this is not the same as Alexander's argument, as it focuses on the subjective mental state of the discriminated rather than the discriminator. For my purposes I can ignore this difference. ${ }^{7}$ See also David Miller's Meritocratic Account (1992, p. 161): 'Justice demands that the job be offered to the best-qualified applicant. We express this by saying that the best-qualified applicant deserves the job or, in a slightly different formulation, that the principle involved is one of merit. This is the principle that condemns discrimination on grounds of sex, race or religion when hiring employees.'
} 
promoting the freedom, health, and well-being of their citizens', the economic contribution potential of prospective immigrants does 'connect to real significance to the society' (MacKay 2016, p. 133). Therefore, unlike a claim about the moral superiority of others, MacKay argues that '[s]tates' interests in economic success and political integration are reasons prospective immigrants cannot reasonably reject as bases for differentiation' (2016, p. 129).

One may challenge the assumption that IBC are indeed in the state's economic interest. Shachar has pointed, for example, to the 'disappointing results' of the Canadian investment visa scheme, and other investment based programmes (Shachar 2017, pp. 801f). Whether this conclusion is generalizable to all investment migration schemes is open to empirical contestation, but nevertheless, if it holds it would suggest that the selection criteria reflect unjustified bias as opposed to justified self-interested. Note however that if this argument is persuasive, SBC may be no less problematic than IBC. As Higgins argues, ' $[\mathrm{a}]$ great deal of empirical research supports the view that the net impact of immigration (even of the 'unskilled') for the economies of relatively wealthy receiving countries is positive in the aggregate' (2013, p. 202 [emphasis added]). If the exclusion of low-skilled migrants is justified by claims that, unlike high-skilled migrants, they will be a fiscal burden on the welfare state or that they will drive down wages for native workers, the empirical evidence for these claims is contested (see Borjas 2014; Card and Peri 2016; Hainmueller and Hiscox 2010).

Whether or not these are reasons that prospective immigrants cannot reasonably reject, it may be that, subjectively, unselected prospective migrants would be insulted by the reasons for which they have not been selected, or find these reasons disrespectful. Ana Tanasoca, in her consideration of this question, argues that 'discriminating on the basis of education is less degrading than discriminating on the basis of money: at least education is a deeper and more stable attribute of the person, unlike merely contingent and perhaps fleeting facts about his pocket' (Tanasoca 2018, p. 66). But it is hard to see why. 'Unskilled' workers may be insulted by the state's policy, either because 'they find it judges their worth to the society on the basis of a factor beyond their control, or deems them less valuable contributors to the community, thereby undermining their self-esteem' (Fine 2016, p. 144).

Indeed, one may even have the reverse intuition: discrimination on the basis of education is more degrading than discrimination on the basis of financial status, precisely because the former is based on enduring features of the person. Tanasoca (2018, pp.66f, fn 42) concedes this intuition with regards to enduring attributes that an agent cannot voluntarily acquire or avoid (either because they are ascribed attributes beyond its control, like race or sexual orientation, or the result of structural injustice 
and lack of opportunities), and so is not responsible for them. ${ }^{8}$ But that is 'obviously not the case with education', which is therefore less arbitrary than financial status. But this dichotomy is unconvincing: it is simply not the case that, categorically, one is more responsible for one's skills and talents than for one's financial status. Individual status of wealth and education are similarly attributed to family background, class privilege, arbitrary psychological dispositions, and structural inequality, not merely personal choice or brute luck. That one is a more enduring fact about the person does not make it less morally arbitrary. In any case, policies based on SBC or IBC do not generally inquire into the causes of one's education or wealth.

\subsection{Objective Meaning}

The second account of the wrongness of discrimination is the Objective Meaning account, as defended by Deborah Hellman (2008). This account grounds the wrong of discrimination in the meaning expressed by such actions within a particular social context; specifically, that discriminating actions are demeaning to affected parties, expressing that the relevant individual and social group to which she belongs are not 'fully human'. Thus, for example, Carens's justification for ruling out race, ethnicity, religion, and sexual orientation as permissible selection criteria is that such exclusions would violate a liberal democratic norm against 'stigmatizing form[s] of discrimination', reflecting 'popular prejudice and uninformed fear rather than a reasonable calculation of the risks and burdens they entail' (Carens 2013, p. 179).

Is it the case, then, that IBC are wrongfully discriminatory because their demeaning social meaning, even when this is not explicitly expressed by the state, or subjectively felt by immigrants? In a critique of Carens's account of social stigma as the root of the wrongness of discrimination, Arash Abizadeh (2014) argues that this is an open question: 'why is it impermissible to discriminate on the basis of religion in the name of the public interest, but permissible do so on the basis of poverty or social class?'. The poor, as a social class, are after all no less stigmatised, or thought of as inferior, than ethnic or sexual minorities. It is possible to argue, furthermore, that even when selection criteria are based on 'neutral' metrics such as the ability to pay, in an unequal world wealth would in fact be a proxy for certain racial, ethnic, or gendered traits. The fact that whites, as a group, have more wealth, status, and political influence 'is not the result of differential innate ability, or a greater degree of industriousness, but is the outcome of several hundred years of transnational as well as intra-national... exploitation, manifest both in greater resources for whites as a racial group... and national and transnational structures which favor whites locally and the European and Euro-settler states globally' (Mills, 2015).

\footnotetext{
${ }^{8}$ A similar challenge was posed to me by an anonymous reviewer.
} 
But if these arguments against IBC are persuasive, then clearly they apply to SBC as well. Desiree Lim, building on Hellman's expressive theory of discrimination, argues that talent-migration in the existing context is a form of wrongful discrimination because it generates a binary with regards the kind of people desired by the society, with low-skilled immigrants as a stand in for undesired foreigners (Lim 2017). Even if the policies themselves are not motivated by xenophobia, they send a social signal about the social traits of foreign unskilled immigrants and their status as a burden on society. Some have made a more radical claim, arguing that SBC reflect a particular value-laden hierarchy of particular skills, elevating male-dominated fields over female-dominated care work, or skills values in the capitalist west over skills valued in other cultures (Tannock 2011).

\subsection{Harm}

Finally, a third possible account of the wrongfulness of discrimination is a consequentialist one. As defended by Kasper Lippert-Rasmussen:

an instance of discrimination is wrong, when it is, because it makes people worse off, i.e., they are worse off given the presence of discrimination than they would have been in some suitable alternative situation in which the relevant instance of discrimination had not taken place (Lippert-Rasmussen 2014, p. 154f).

Race-based selection criteria, therefore, may be wrongfully discriminating when they are harmful to the most vulnerable groups: due to discrimination, they are worse off than they would be in a just world. For example, as Higgins writes, 'virtually all past or ongoing exclusions on the basis of (imagined) race, religion, and sexual preference are plainly unjust', because the denial of admission has avoidably harmed the excluded vulnerable groups (2013, p. 208).

With regards to SBC and IBC, the harm-based account is ambiguous. Whether or not the unselected prospective immigrants are harmed by the policy would depend on the baseline for assessing harm. Presumably, since they are voluntarily applying to be admitted, they at least believe they would be better off if admitted to the selecting state, and so are worse off compared to that counterfactual. Yet that is an implausible place to set baseline, as it will set all cases of discrimination as wrongful. More importantly, if this baseline is accepted, it does not allow a distinction between SBC and IBC.

Moralizing the baseline complicates things further. As I stated in my preliminary assumptions, the case in question is one of discretionary migration where state is not under obligation to accept any of the prospective immigrants, although it is required to provide a justification for excluding them. In other words, since a possible world in 
which the state uses its discretion to admit no further immigrants is not unjust, the prospective immigrant cannot be said to be harmed by the selection criteria: the state was not under duty to admit them. The criteria specified in different policies of SBC and IBC migration provide the justification for exclusion. Not all justifications are created equal, of course; but unless we can explain why SBC are justifiable criteria while IBC are unjustifiable, our judgement with regards to the harms imposed by the two policies should be the same.

\section{The Equality of Opportunity Objection}

\subsection{Global Equality of Opportunity}

IBC may be wrong not because they are wrongfully discriminatory, but because they are unfair. ${ }^{9}$ Chris Armstrong (2018, p. 27) suggests this possibility when he writes that 'perhaps it is unfair to allow people to buy citizenship, because other less fortunate outsiders are thereby disadvantaged... The playing-field is simply not even'. ${ }^{10}$ Similarly, Tanasoca (2018, p. 66) writes that investor citizenship is unjust because '[a]11 otherwise identically situated individuals should have equal opportunities of becoming citizens, no matter their financial situation'.

It is not obvious, however, that even if we accept a strong global principle of equality of opportunity, all individuals should have an equal opportunity to become citizens of a particular state. Even cosmopolitan supporters of global equality of opportunity do not endorse this position. Simon Caney, for example, argues that we should aim not to secure equal access to the same positions, but for equal opportunity to fill social positions of equal value in terms of the rewards attached to them (Caney 2001). And to reiterate the background assumptions of this discussion: the prospective immigrants in question do not have a particular right to be admitted to the selecting state, so it does not follow that they should have an equal opportunity to be admitted. Given that investment-based migration is not the sole route for migration, it is not clear why it is problematic that 'investor citizenship makes available to the rich and only to the rich an extra naturalization route, over and above the standard one that is available to the rich and poor alike' (Tanasoca 2018, p. 66).

Even if we accept this line of thought, Tanasoca's argument seems ad-hoc; it is not clear in what sense two individuals with different financial situations are 'identically

\footnotetext{
9 Whether wrongful discrimination should be defined in terms of inequality of opportunity is a contested position; see (Segall 2012, p. 83, fn4) for the claim that this position is almost universally rejected amongst theorists of discrimination.

${ }^{10}$ Note that Armstrong only proposes this argument, but does not endorse it; he recognizes that this objection is not to selling citizenship per se, but to facilitating easy access to the wealthy, as well as the skilful.
} 
situated'. This already assumes that the ability to pay more is irrelevant to the question of equal opportunity, which is the desired conclusion. Why, in other words, couldn't Tanasoca write that SBC are unjust because 'all otherwise identically situated individuals should arguably have an equal opportunity of becoming citizens, regardless of their levels of education, or their profession'?

\subsection{Complex Equality}

A more sophisticated version of this argument, defended by Ayelet Shachar, is that 'turning citizenship into a money-based prize also contradicts any Walzerian-like notion of complex equality according to which advantage in one sphere (here, wealth) cannot be legitimately transferred to another (in this case, membership)' (Shachar 2018 , p. 13). For the sake of argument, I will set aside the question of whether complex equality as distributive principle can be thought to apply globally, and not, as Walzer conceived it, as restricted to a bounded community with shared understandings of the meaning of social goods. ${ }^{11}$ I also accept that, for the sake of argument, membership can be conceived as one of the goods or spheres in question, as opposed to being the background assumption against which the demand for complex equality arises (Miller 1995). ${ }^{12}$

Suppose then that we apply the ideal of complex equality to the question at hand. In defining complex equality, Walzer writes that 'No social good $X$ should be distributed to men and women who possess some other good Y merely because they possess $Y$ and without regard to the meaning of $X^{\prime}$ ' (Walzer 1983, p. 20). For Shachar's argument to work, we need to replace 'social good $X^{\prime}$ with 'political membership'; We need a theory of the meaning of political membership, and then decide what kind of distributive principle arises from this meaning; And then we need to show that selecting by the ability to pay (that is, exchanging wealth for political membership) violates this principle, whereas selecting by skill does not.

The presumed problem with IBC, from the perspective of complex equality, is either that the distributive logic of allocating money is not the same as the one allocating citizenship (and so advantage in the sphere of the economy translates into advantage in the sphere of political membership); or that the distributive logic governing membership allocation is different than the market logic of free exchange, and thus allowing money to be exchanged for citizenship would entail the tyranny of market over citizenship. Shachar's own ground-breaking work, and her critique of birthright citizenship, suggests the latter interpretation: given the meaning of citizenship, it

\footnotetext{
${ }^{11}$ For the argument that this is the implication of Walzer's theory, see (Barry 1995; Miller 1995).

12 This is a common assumption in anti-commodification arguments (e.g. Sandel, Anderson, and Satz), which makes their argument inapplicable to the question of whether citizenship itself could be for sale.
} 
should allocated according to social connections (jus nexi). But if this is the case, SBC clearly also fall short.

Shachar and Hirschl (2014) anticipate this objection, and attempt to evade it by offering a distinction between human capital and capital simpliciter. On the one hand, they maintain that selecting by the ability to pay is arbitrary: 'there is no rational connection between delivering a stack of cash or sending in a bank wire transfer and establishing the kind of participation and equal standing among fellow citizens that the political bonds of membership are meant to represent and foster' (2014, p. 250). But 'a similar conclusion is not warranted' with regards to high-skilled migration programs: IBC which 'depend on the alienability and transferability of purely fungible funds, [SBC] focus on the distinctive skills, talents, or abilities 'encapsulated' in the recruited migrant herself who moves to the new country'. Human capital, unlike capital simpliciter, 'is non-transferable and non-alienable; it is part of the self', and so protected by considerations of personal liberty (2014, p. 251).

However, recognising the conceptual distinction between non-transferable, nonalienable, self-bounded human capital, on the one hand, and fungible, impersonal capital on the other hand, does not immediately entail that the former can legitimately serve as criteria for membership, but not the latter. MacKay (2016, p. 137) rightly points out that religion, race, ethnicity, and sexual orientation are also non-alienable, non-transferable, identity-bound traits, but this in itself does not entail that they can serve as criteria for membership. Nor can the distinction be made on the basis that talent or skills are more conceptually connected to membership because their contribution extends over a longer time period (potentially, the lifespan of the person), whereas financial contribution can be made in a matter of seconds. As Armstrong $(2018,25 f)$ argues, the significance and depth of contribution is not necessarily linked to the duration in which this contribution has taken place.

We may concur with Paulina Ochoa (2018, pp. 45f), instead, that the deciding factor is physical presence. This is more persuasive: for human capital to be productive, it usually requires the presence of the individual, and is conceptually connected to residence and membership. But note that this is an objection to waiving residence requirements for membership, not to the kind of criteria used for selecting prospective immigrants. It will rule out passport-for-sale schemes (where investors become citizens without any residence requirements), but not golden visa programs, which grant residence rights. Interestingly, this kind of objection would also apply to certain (although admittedly rarer) SBC migration policies - for example, the naturalisation of Olympic athletes.

We may alternatively think that given the social meaning of citizenship, it is appropriate to allocate it to those who have the greatest potential to become good 
citizens. Having available the sums required to meet IBC is not an indication of citizenship potential, and so it is an illegitimate consideration. Along these lines, Tanasoca (2018, p. 67) argues that unlike the direct exchange of money for citizenship, 'one gets citizenship exclusively for performing well in naturalization tests, not directly for the diplomas hanging on one's wall'. But this is misleading. We should not conflate civic education, or successful passing of a naturalisation test, with the kinds of educational requirements for meeting SBC. Most existing SBC reward skills required in the job market, not in the political sphere. Even if we accept a meritocratic principle of awarding citizenship, it is not clear why selecting for job market skills is more legitimate than selecting by ability to invest.

So far I've been assuming that, as in the real world, investment-based immigration in addition to other forms of immigration, discretionary and non-discretionary. However, wouldn't it become wrongfully unfair if 'the size of their wallets, and nothing else, distinguishes suitable from unsuitable candidates for initial entry and eventual citizenship'? (Shachar and Hirschl 2014, p. 250) ${ }^{13}$ If market logic completely takes over the admission of immigrants and the allocation of citizenship, would-be entrants who might have had a shot through standard migration streams would be 'priced out', and 'auction mechanisms and supply-and-demand rules may well replace our (however imperfect) procedures for ensuring some degree of accountability and collective decision-making on what it means to belong to a political community' (Shachar and Hirschl 2014, p. 248).

Yet it is important to avoid conflating selection by the ability to pay (as is already the case in existing investor-migrant schemes), and a complete capitulation of state sovereignty to market forces, as is imagined in this dystopian scenario. Even so, it is not obvious that investor migration would lead to a reduction in non-investor based migration. From a purely economic perspective, at least, the case is not settled. Javier Hidalgo (2016, p. 237, fn19), for example, argues that we should avoid thinking about immigration as a zero-sum game, and it is possible that adding investor migrants will increase the quota of migrants a state is willing to accept, given that it would now have more material resources. This is an empirical question, and as Hidalgo himself

\footnotetext{
${ }^{13}$ See also on p. 251: 'The problem, we believe, lies not in the selection of some migrants to join our political committees based on their extraordinary talent or potential to generate reputational gains and positive externalities. The different selection criteria for admitting newcomers-family based, humanitarian, and employment-based-serve different purposes and follow distinctive logics. There is no principled reason to presuppose that any of them, standing alone, can respond to the full spectrum of human motivation for mobility. The danger lies elsewhere: in the totalizing impact of turning talent and human capital into the make-or-break criteria for cross-border mobility, and the consequent emergence of a more stratified perception of membership goods as 'Olympic laurels' to be awarded by competitive nations only to those they covet most'. The same applies, mutatis mutandis, to selection by investment.
} 
concedes, in the absence of solid evidence 'it is hard to say for sure whether selling citizenship would unfairly displace deserving applicants or not'.

In any case, a world in which meeting SBC is the only route for admission would be equally damaging to the equality of opportunity. Indeed, there is compelling evidence that the rise of high-skilled migration schemes is correlated with new restrictions and conditionalities on low-skilled migration, as well as on supposedly non-discretionary admissions, such as family-based migration and asylum (Kofman 2018; Ellermann forthcoming). While it is true that 'we must also be cautious not to assume a causal link between the instrumental and strategic considerations that fuel the fires of talent migration and the stricter mobility-curbing measures imposed upon other streams of migration' (Shachar 2016), a similar logic fuels both the move to attract 'the best and brightest', and to restrict access of those considered a burden (Ypi 2018; Ellermann forthcoming).

\section{The Political Equality Objection}

So far I have been focusing on justificatory constraints on selection criteria with regards to prospective, unselected immigrants. Both the discrimination and equality of opportunity arguments assume that the state has a duty to treat prospective immigrants equally and fairly. The line of argument I turn to now is far less controversial: it only claims that the criteria for selecting prospective immigrants should be justifiable to the state's current citizens. As such, this is the line of thought endorsed by theorists of immigration most opposed to open borders (Blake 2002; Wellman and Cole 2011; Miller 2016).

\subsection{Basic Interests}

One possible line of argument is that selection criteria do not meet the burden of justification if they do not sufficiently protect current citizens' basic interests. Thus, for example, it is argued that the state is required to exclude potential immigrants if they have a criminal history, or, with regards to low-skilled immigrants, if their admission would have potential harmful effect on low-skilled domestic labour. But the case is much harder to substantiate either with regards to investment-based or skill-based selection criteria, where it is already assumed that the state is selecting by potential contribution to the economy. As I already argued above, whether any particular scheme actually delivers these expected results is a different question, but one that applies equally to both types of selection criteria.

Particular instances of IBC may, of course, have harmful effects for current citizens. On June 2017, Canada announced that its electronic Travel authorisation (eTA) for citizens of Antigua and Barbuda will become null and void. Several media reports to 
speculate the decision was motivated by the Antiguan Citizenship by Investment Program, in line with a similar decision to revoke St. Kitts and Nevis's no-visa travel. Shachar cites these cases as examples of 'non-monetary sanction and suspicion that Kittians and Nevisians [and Antiguans] who have no other passport... must now bear' (Shachar 2017, p. 803). But these harmful effects are contingent to investment-based criteria (no such measures were suggested against Malta, for example), and could equally arise from other immigration policies who were too lax in the view of third parties.

\subsection{Expressive Harm}

A more foundational way to conceive the wrongs to current citizens is to focus on the expressive harms of immigration law in general, and selection criteria in particular, on current citizens. Within normative political theory, Michael Blake endorses this argument as an explanation of the wrongness of race-based selection criteria. These are wrong not because they are discriminatory towards prospective immigrants, he argued, but because they reflect a message of racial favoritism on behalf of the state. This is doubly wrong, as 'this statement undermines the ability of citizens with the disfavored racial identity to see themselves as full participants in the project of selfrule', and undermines the political equality of fellow citizens within the state (Blake 2002, 284). Within legal theory, Adam Cox analogises immigration law to redistricting laws, both concerning the regulation of political community boundaries, and relies on the supreme court ruling against racial gerrymandering in Shaw vs Reno to conclude that immigration laws could regulate the boundaries of the national political community in a fashion that expresses a constitutionally impermissible national political identity' (Cox 2004, p. 401).

Several critics of IBC have employed this expressive interpretation. Shachar and Hirschl argue that ' $[\mathrm{t}]$ he sale and barter of citizenship ... nevertheless sends a loud message in both law and social ethics about whom the contemporary market-friendly state gives priority to in the immigration and naturalisation line and whom it covets most as future citizens' $(2014,247)$. Tanasoca suggests that selling citizenship would have the expressive effect of damaging exiting citizens' self-esteem: '[t]he sale implicitly equates group membership to a pile of money' $(2018$, p. 75).

At the first instance, a possible response here is that, as Hidalgo argues, 'any criterion that a state uses to regulate access to citizenship expresses the message that this state values certain attributes over others' (2016, p. 232). For example, making it easier for nuclear physicists to immigrate communicates the message that the state values nuclear physicists more than other kinds of people. As this policy seems permissible, selling citizenship should be permissible. Armstrong makes a similar argument for the opposite conclusion: he agrees with Shachar that the concern about the expressive 
effects of selling citizenship is a profound one, but maintains that its implications ripple beyond the mere selling of citizenship', as a policy which makes it easier for highly-skilled people to obtain citizenship would have the same effect (Armstrong 2018, p. 27).

\subsection{Expressive Preference vs Expressive Precondition}

This however, is too quick. Just as the fact that all selection criteria are discriminating in the broad sense is not sufficient for determining that all forms of discrimination are wrong, the fact that all selection criteria have expressive effects vis-à-vis current citizens is not sufficient for determining that they are expressive harms. As it is notoriously difficult to establish what precisely is the expressive meaning of a particular law, it is important to distinguish between two kinds of attitudes expressed by the state when it employs selective criteria immigration and naturalisation policies:

(1) Expressive Preference: The state expresses the view that it prefers its citizens to be $X$, or to have the traits of $X$.

(2) Expressive Precondition: The state expresses the view that being $X$, or having the traits of $X$, is a necessary precondition for being an equal citizen.

Once we determine the expressive effect of the law, we can turn to consider its permissibility. With the political equality argument, the concern is one of integrity of purpose: if the state is not permitted to express a preference for a certain group identity or trait $X$ domestically, or establish that $X$ is a precondition for citizenship with its own citizens, it is not also permitted to do so towards prospective immigrants.

With this in mind, consider the difference between three criteria $(X)$, which will serve as ideal types:

(i) Engaging in terrorist activity;

(ii) Having a criminal record;

(iii) Being a member of a minority religious group.

A discretionary immigration policy that excludes members of terrorist organisations seems the least objectionable, as it expresses the state's opposition to terrorism which is also reflected in domestic security policies, on the one hand, and the expatriation of citizens engaged in terrorist activity, on the other hand. ${ }^{14}$ In comparison, states' exclusion of prospective immigrants with criminal records, or stating that a clean criminal record is a requirement for naturalisation, plausibly has the expressive effect toward current citizens that engaging in crime are less desired by the state, and that

\footnotetext{
14 The latter being more controversial, of course, and some have argued that expatriation of terrorists is not compatible with democratic conceptions of citizenship. See (Lenard 2018).
} 
having a criminal record undermines one's standing as an equal citizen. The first attitude is arguably permissible - the state has justifiable reasons to prefer its citizens to be law-abiding - while the second is more controversial, as is reflected in debates over felon disenfranchisement. ${ }^{15}$ In comparison, the state's expressed preference for a particular ethnic or religious group is the least justifiable, even if it does not actively take away political rights from other groups. It is objectionable on grounds of political equality because the state's expressed interest in increasing the share of people from a specific religious or ethnic group communicates to others that the state views them as, at best, a burden to be tolerated.

We may disagree on the precise evaluation of each of these criteria, but the point here is that any specific criterion may be impermissible given its expressive preference, or expressive precondition, or both. When evaluating the compatibility of any selection criterion with political equality, it is necessary to determine first, what is its expressive effect, and second, whether this would be permissible towards current citizens. Consider, for example, selection criteria excluding or penalising people with disabilities. Mathew Lindauer argues that incorporating such selection criteria would be impermissible on grounds of political equality, as it would express that only ablebodies people qualify as citizens (Lindauer 2017, pp. 289f). ${ }^{16}$ This implicitly takes immigration selection criteria as expressing a precondition, which would be impermissible.

I argue, conversely, that selective criteria of immigration such as IBC and SBC do not have expressive content on the preconditions of citizenship, but only with regards to state preference. As MacKay rightly points out with regards to SBC, '[s]tates do not commit themselves to the claim that unskilled citizens are somehow unfit for political membership... They only commit themselves to the claim that skill is valuable and a legitimate reason for favoring one prospective immigrant over another, all of whom skilled or unskilled - may be fit for political membership' (2016, p. 135). The point is equally valid to other selection criteria, including IBC. Importantly, and as I have already argued above, as no state employs a single criterion for admitting immigrants, it is difficult to say what is the singular message it conveys about its preconditions for citizenship; indeed, it is more plausible to claim that there are several sufficient preconditions, and that unlike prospective immigrants, current citizens meet these preconditions by virtue of being born to citizens (jus sanguinis) or being born in the state's territory (jus soli).

\footnotetext{
${ }^{15}$ For normative defences and objections to the practice, see (Manfredi 1998; Reiman 2005).

${ }^{16}$ Citing approvingly statements opposing such criteria by The Council of Canadians with Disabilities, and The Australian organization COTA (formerly the Council on the Ageing), respectively.
} 
This, however, does not settle the question of whether these criteria are permissible or not from the perspective of political equality, since it could be argued that the state's expressive preference is impermissible, even domestically. Consider again of the example of the religion-based criterion above, which is impermissible even as an expressive preference. Can we say the same about IBC or SBC?

Expressed preference for electrical engineers or computer programmers over agricultural or domestic workers arguably carries the message that the state values these skills more highly, and considers life spent in the pursuit of academic knowledge more valuable (Tannock 2011) ${ }^{17}$ Is this a permissible attitude? Given prominent views of liberal state neutrality, the answer is no: it is impermissible for the state to express any value judgement on its citizens' conception of the good life. If we accept this view, Shachar is right to argue that SBC are in tension with certain liberal conceptions of equal citizenship, albeit not because 'democratic and egalitarian notions which at least formally assign membership to individuals irrespective of how innovative, talented, or accomplished they may (or may not) be' (2016, p. 197), but because liberal conceptions of equal citizenship are supposed to be neutral with regards to the value of their citizens' conception of the good life.

Note that this conclusion relies on a very particular understanding of liberal state neutrality, which is susceptible to at least three objections. First, one may hold that SBC/ IBC violate state neutrality, but that this is a pro tanto concern overridden by the social benefits of such policies. Second, one might interpret state neutrality as neutrality of justification, and argue that SBC/IBC do not violate neutrality as they can be justified through public reason. Finally, one can of course follow a long line of perfectionist critics and reject the principle of state neutrality altogether. ${ }^{18}$ None of these positions, however, provide a clear cut distinction between SBC and IBC.

A surprising upshot of this line of argument is that it holds more strongly for SBC than for IBC, at least from within the common arguments of liberal neutralism. The neutral liberal state is neutral towards conceptions of the good life, and therefore ought not to express its preference of particular professions, skills, or levels of education. But it should not be neutral towards primary goods - and income and wealth are, after all, primary social goods (Rawls 1971). By expressing a preference towards money, the state is not expressing any preference for any particular conception of the good life, and thus cannot be said to violate considerations of liberal neutrality.

\footnotetext{
${ }^{17}$ See also (Boucher 2016; Lim forthcoming) on the gender-bias in these evaluations.

${ }^{18}$ I thank an anonymous reviewer for suggesting this objection.
} 


\section{Conclusion}

I have offered a critical analysis of three prominent normative objections to investment-based selection criteria for immigrants (IBC), comparing it to skill-based criteria (SBC). I have argued that under certain relatively uncontroversial background assumptions, either the arguments against IBC fail, or also apply to SBC. To recap the analysis:

(1) The Wrongful Discrimination Objection is either too weak, or also applies to $\mathrm{SBC}$, depending on the theory of wrongful discrimination in play.

(2) The Equality of Opportunity Objection does not apply in our world of plural migration routes; otherwise it applies equally to IBC and SBC.

(3) The Political Equality Objection, if it applies, suggests that SBC are less justified than IBC.

If persuasive, my analysis places us at the horns of a dilemma. The existing objections, and the ways to answer them, seem to apply equally to SBC and IBC. Does it entail that accepting $I B C$, or rejecting $\mathrm{SBC}$ ? Each of these results would have major implications. Choosing the first horn would run counter to accepted views in both scholarship and public opinion; opting for the latter raises further questions, mainly whether there are any permissible selection criteria for discretionary migration, or whether states must rely on arbitrary decision mechanisms, such as lotteries.

There may be ways to avoid this dilemma, of course. One would be to offer new arguments for rejecting IBC, which would not equally apply to SBC. Alternatively, and more radically, resisting the conclusion of this article may require revisiting, and perhaps revising, the background assumptions on which it relies. Since these are widespread assumptions in the ethics of migration, that would be a surprising outcome.

\section{References}

Abizadeh, A. 2008. 'Democratic Theory and Border Coercion'. Political Theory 36 (1): 3765.

. 2014. 'Review of The Ethics of Immigration by Joseph H. Carens'. Notre Dame Philosophical Reviews. 28 April 2014. https://ndpr.nd.edu/news/the-ethics-ofimmigration/.

Abrahamian, A. 2015. The Cosmopolites: The Coming of the Global Citizen. (New York, NY: Columbia Global Reports).

Alexander, L. 1992. 'What Makes Wrongful Discrimination Wrong Biases, Preferences, Stereotypes, and Proxies'. University of Pennsylvania Law Review 141 (1): 149-220. . 2016. 'Is Wrongful Discrimination Really Wrong?'. San Diego Legal Studies Paper No. 17-257. https://papers.ssrn.com/abstract=2909277. 
Armstrong, C. 2018. 'The Price of Selling Citizenship.' In Debating Transformations of National Citizenship edited by R. Bauböck. (Cham: Springer: 25-28).

Barry, B. 1995. 'Spherical Justice and Global Injustice.' In Pluralism, Justice, and Equality edited by David Miller and Michael Walzer. (Oxford: Oxford University Press: 67-80).

Becker, G., and And Edward P. Lazear. 2013. 'A Market Solution to Immigration Reform'. Wall Street Journal, March 2, 2013, sec. Opinion. http://www.wsj.com/articles/SB10001424127887323375204578271531542362850.

Blake, M. 2002. 'Discretionary Immigration'. Philosophical Topics 30 (2): 273-89. . 2008. 'Immigration and Political Equality'. San Diego Law Review 45: 963-80.

Borjas, G. 2014. Immigration Economics. (Cambridge, MA: Harvard University Press).

Borna, S, and J.M. Stearns. 2002. 'The Ethics and Efficacy of Selling National Citizenship'. Journal of Business Ethics 37 (2): 193-207.

Boucher, A. 2016. Gender, Migration and the Global Race for Talent. (Oxford: Oxford University Press).

Brennan, J, and P.M. Jaworski. 2015. 'Markets without Symbolic Limits'. Ethics 125 (4): 1053-77.

Brock, G, and M. Blake. 2014. Debating Brain Drain: May Governments Restrict Emigration? (Oxford: Oxford University Press).

Mills, C. 2015. 'Race and Global Justice' In Domination and Global Political Justice: Conceptual, Historical and Institutional Perspectives edited by B. Buckinx, J. TrejoMathys and T. Waligore, (New York, NY and Abingdon: Routledge: 181-205).

Caney, S. 2001. 'Cosmopolitan Justice and Equalizing Opportunities'. Metaphilosophy 32 (12): $113-34$.

Card, D, and G. Peri. 2016. 'Immigration Economics by George J. Borjas: A Review Essay'. Journal of Economic Literature 54 (4): 1333-49.

Carens, J. 2013. The Ethics of Immigration. (New York, NY: Oxford University Press).

Cole, P. 2014. 'Beyond Reason: The Philosophy and Politics of Immigration'. Critical Review of International Social and Political Philosophy 17 (5): 503-20.

Cox, A. 2004. 'Citizenship, Standing, and Immigration Law'. California Law Review 92 (2): 373-424.

Czaika, M, and C.R. Parsons. 2017. 'The Gravity of High-Skilled Migration Policies'. Demography 54 (2): 603-30.

Džankić, J. 2019. The Global Market for Investor Citizenship. (Cham: Springer).

Ellermann, A. forthcoming. 'Human-Capital Citizenship and the Changing Logic of Immigrant Admissions'. Journal of Ethnic and Migration Studies.

European Parliament. 2014. 'Resolution on EU Citizenship for Sale, 2013/2995(RSP).'

Ferracioli, L. 2017. 'Citizenship Allocation and Withdrawal: Some Normative Issues'. Philosophy Compass 12 (12): e12459.

Fine, S. 2016. 'Immigration and Discrimination.' In Migration in Political Theory: The Ethics of Movement and Membership edited by S. Fine and L. Ypi. (Oxford: Oxford University Press): 125-150.

Fine, S, and L. Ypi. 2016. Migration in Political Theory: The Ethics of Movement and Membership. (Oxford: Oxford University Press).

Goodin, R.E. 2007. 'Enfranchising All Affected Interests, and Its Alternatives'. Philosophy \& Public Affairs 35 (1): 40-68.

Hainmueller, J, and M.J. Hiscox. 2010. 'Attitudes toward Highly Skilled and Low-Skilled Immigration: Evidence from a Survey Experiment'. American Political Science Review 104 (1): 61-84.

Hellman, D. 2008. When Is Discrimination Wrong? (Cambridge, MA: Harvard University Press). 
Hidalgo, J. 2016. 'Selling Citizenship: A Defence'. Journal of Applied Philosophy 33 (3): 22339.

Higgins, P. 2013. Immigration Justice. (Edinburgh: Edinburgh University Press).

Johnston, L. 2013. 'A Passport at Any Price? Citizenship by Investment Through the Prism of Institutional Corruption'. ID 2324101. Edmond J. Safra Research Lab Working Papers. (Harvard, MA: Endmond J. Safra Center for Ethics). https://papers.ssrn.com/abstract=2324101.

Joppke, C. 2005. Selecting by Origin: Ethnic Migration in the Liberal State. (Cambridge, MA: Harvard University Press).

Kofman, E. 2018. 'Family Migration as a Class Matter'. International Migration 56 (4): 3346.

Lenard, P.T. 2018. 'Democratic Citizenship and Denationalization'. American Political Science Review 112 (1): 99-111.

Lim, D. 2017. 'Selecting Immigrants By Skill: A Case Of Wrongful Discrimination?' Social Theory \& Practice 43 (2): 369-96.

. forthcoming. 'The Indirect Gender Discrimination of Skill-Selective Immigration Policies'. Critical Review of International Social and Political Philosophy.

Lindauer, M. 2017. 'Immigration Policy and Identification Across Borders'. Journal of Ethics and Social Philosophy 12 (3).

Lippert-Rasmussen, K. 2014. Born Free and Equal?: A Philosophical Inquiry Into the Nature of Discrimination. (New York, NY: Oxford University Press).

MacKay, D. 2016. 'Are Skill-Selective Immigration Policies Just?' Social Theory and Practice 42 (1): $123-54$.

Manfredi, C.P. 1998. 'Judicial Review and Criminal Disenfranchisement in the United States and Canada.' The Review of Politics 60 (2): 277-306.

Miller, D. 1992. 'Deserving Jobs.' The Philosophical Quarterly (1950-) 42 (167): 161-81.

- 1995. 'Complex Equality.' In Pluralism, Justice, and Equality, edited by David Miller and Michael Walzer. (Oxford: Oxford University Press): 197-225.

- 2016. Strangers in Our Midst. (Cambridge, MA: Harvard University Press).

Ochoa, P. 2018. 'What Money Can't Buy: Face-to-Face Cooperation and Local Democratic Life.' In Debating Transformations of National Citizenship edited by R. Bauböck. (Cham: Springer): 43-46.

Parker, O. 2017. 'Commercializing Citizenship in Crisis EU: The Case of Immigrant Investor Programmes.' JCMS: Journal of Common Market Studies 55 (2): 332-348.

Pevnick, R. 2011. Immigration and the Constraints of Justice: Between Open Borders and Absolute Sovereignty. (Cambridge: Cambridge University Press).

Rawls, J. 1971. A Theory of Justice. (Cambridge, MA: Harvard University Press).

Reiman, J. 2005. 'Liberal and Republican Arguments Against the Disenfranchisement of Felons'. Criminal Justice Ethics 24 (1): 3-18.

Sager, A. 2016. 'Methodological Nationalism, Migration and Political Theory'. Political Studies 64 (1): 42-59.

Segall, S. 2012. 'What's so Bad about Discrimination?' Utilitas 24 (1): 82-100.

Shachar, A. 2016. 'Selecting By Merit.' In Migration in Political Theory: The Ethics of Movement and Membership, edited by S. Fine and L. Ypi. (Oxford: Oxford University Press): 165-204.

. 2017. 'Citizenship for Sale?' In The Oxford Handbook of Citizenship, edited by A. Shachar, R. Bauböck, Irene Bloemraad, and Maarten Peter Vink, 789-815. (Oxford: Oxford University Press): 786-816. 2018. 'Dangerous Liaisons: Money and Citizenship' In Debating Transformations of National Citizenship edited by R. Bauböck. (Cham: Springer: 7-16). 
Shachar, A, and R. Hirschl. 2014. 'On Citizenship, States, and Markets' Journal of Political Philosophy 22 (2): 231-57.

Tanasoca, A. 2018. The Ethics of Multiple Citizenship. (Cambridge; New York, NY: Cambridge University Press).

Tannock, S. 2011. 'Points of Prejudice: Education-Based Discrimination in Canada's Immigration System'. Antipode 43 (4): 1330-56.

Van Fossen, A. 2007. 'Citizenship for Sale: Passports of Convenience from Pacific Island Tax Havens.' Commonwealth \& Comparative Politics 45 (2): 138-63.

Walzer, M. 1983. Spheres of Justice: A Defense Of Pluralism And Equality. (New York, NY: Basic Books).

Wellman, C.H, and P. Cole. 2011. Debating the Ethics of Immigration: Is There a Right to Exclude? (New York, NY: Oxford University Press).

Yong, C. 2017. 'Immigration Rights and the Justification of Immigration Restrictions' Journal of Social Philosophy 48 (4): 461-80.

Ypi, L. 2018. 'Borders of Class: Migration and Citizenship in the Capitalist State.' Ethics \& International Affairs 32 (2): 141-52. 